\title{
ALTERNATIF PENINGKATAN PENDAPATAN MASYARAKAT NELAYAN MELALUI OLAHAN BAKSO IKAN RUMPUT LAUT SEBAGAI INOVASI MAKANAN SEHAT DAN RENDAH LEMAK DI DESA TOROKEKU KECAMATAN TINANGGEA KABUPATEN KONAWE
}

Sukmawati Abdullah ${ }^{1 *}$, Bunyamin ${ }^{2}$, Tjandra Buana ${ }^{1}$, Nur Isiyana Wianti ${ }^{1}$, Suriana ${ }^{1}$, Ima Astuty Wunawarsih ${ }^{1}$, Gamal Abdel Nasser ${ }^{2}$

${ }^{1}$ Fakultas Pertanian, Universitas Halu Oleo, Kendari

${ }^{2}$ Fakultas Teknik, Universitas Halu Oleo, Kendari

Korespondensi: Sukmawati Abdullah (*sukmawati.abdullah faperta@uho.ac.id)

\section{RINGKASAN}

Pada perkembangannya pengolahan rumput laut semakin berkembang khususnya di bidang kuliner. Salah satu desa yang memiliki potensi dalam pengembangan rumput lautnya adalah Desa Torokeku Kecanatan Tinanggea Kabupaten Konawe Selatan yang sesuai untuk dijadikan lokasi dalam kegiatan pelatihan pengolahan hasil perikanan yaitu olahan bakso ikan rumput laut. Kegiatan pengabdian kepada masyarakat yang berjudul "Alternatif Peningkatan Pendapatan Masyarakat Nelayan Melalui Olahan Bakso Ikan Rumput Laut Sebagai Inovasi Makanan Sehat Dan Rendah Lemak Di Desa Torokeku Kecamatan Tinanggea Kabupaten Konawe Selatan" bertujuan untuk mengetahui kondisi sosial ekonomi masyarakat di Desa Torokeku, mengetahui bagaimana peningkatan pendapatan masyarakat nelayan melalui olahan bakso ikan rumput laut sebagai inovasi makanan sehat dan rendah lemak di Desa Torokeku, dan mengetahui proses pengolahan bakso ikan rumput laut. Metode pelaksanaan kegiatan pengabdian melalui 3 tahapan yaitu tahap persiapan, pelaksanaan pelatihan, dan tahapan evaluasi. Hasil pelatihan diharapkan peserta pengabdian tertarik mengikuti pelatihan-pelatihan diversifikasi olahan bakso ikan rumput laut, sehingga dapat membuka wawasan khalayak sasaran yang memiliki kemampuan untuk mengolah hasil-hasil laut yang ada di lokasi mereka khususnya rumput laut dan mampu memasarkan produk yang dihasilkan, bahkan dapat dapat dipasarkan secara online melalui penggunaan atau pemanfaatan media elektronik atau internet sehingga mampu menjangkau pasar yang lebih luas dengan biaya rendah, dan pada sasaran kegiatan adalah terbentuknya kemandirian mitra dalam hal jaringan pemasaran, secara lebih luas, sehingga mitra memiliki media promosi produk aneka olahan ikan dalam bentuk brosur/leaflet, CD promosi, serta website, aneka olahan bakso ikan rumput laut yang diproduksi oleh mitra dapat dikemas dengan kemasan sesuai standar kemasan, proses produksi pembuatan olahan bakso ikan rumput laut dapat terjaga higienisnya dengan peralatan khusus untuk pembuatan olahan bakso ikan rumput sehingga sasaran kegiatan hasilnya berdampak pada peningkatan pendapatan dan kesejahteraan keluarga.

Kata Kunci: masyarakat nelayan, olahan bakso ikan rumput laut, pemasaran, pendapatan 


\section{A. PENDAHULUAN}

\section{Analisis Situasi}

Rumput laut adalah salah satu sumber daya hayati (salah satu sumber daya dapat pulih "renewable resources"yang terdi riatas flora dan fauna) yang terdapat di wilayah pesisir dan laut. Dalam bahasa Inggris, rumput laut diartikan sebagai "Seaweed".Sumber daya ini biasanya dapat ditemui di perairan yang berasosiasi dengan keberadaan ekosistem terumbu karang. Rumput laut alam biasanya dapat hidup di atas substrat pasir dan karang mati. Beberapa daerah pantai di bagian selatan Jawa dan pantai barat Sumatera, rumput laut banyak ditemukan hidup di atas karang-karang terjal yang melindungi pantai dari deburan ombak.

Rumput laut atau makro algae sudah sejak lama di Indonesia dikenal sebagai bahan makanan tambahan, sayuran, dan obat tradisional. Rumput laut menghasilkan senyawa koloid yang disebut fikokoloid, yakni agar, align, dan karaginan (Kadi 2004; Handayani et al. 2004). Jenis rumput laut banyak dimanfaatkan karena mempunyai komposisi kandungan yang lengkap seperti karbohidrat yang tinggi, 25-35 protein dari berat kering, mineral (terutama iodine), li-pid, sterol, asam amino, omega-3 \& omega-6, anti-oksidan, hormon pertumbuhan, polifenol, dan flavonoid serta vitamin C (Suparmi \& Sahri 2009; Dewi 2012). Hasil Kajian Ilalqisny dan Widyartini (2000) bahwa sejak tahun 2700 SM rumput laut telah dimanfaatkan sebagai bahan pangan.

Rumput laut merupakan tumbuhan laut jenis alga. Tanaman ini adalah gangang multi seluler golongan divisi thallophyta. Berbeda dengan tanaman sempurna pada umumnya, rumput laut tidak memiliki akar, batang dan daun. Jenis rumput laut sangat beragam, mulai dari yang berbentuk bulat, pipih, tabung atau seperti ranting dahan bercabang-cabang. Seperti layaknya tanaman darat pada umumnya, rumput laut juga memiliki klorofil atau pigmen warna yang lain. Secara umum, rumput laut yang dapat dimakan adalah jenis ganggang biru (cyanophyceae), ganggang hijau (chlorophyceae), ganggang merah (rodophyceae) atau ganggang coklat (phaeophyceae). Hidup bebas di alam, beberapa jenis rumput laut juga banyak dibudi dayakan oleh sebagian masyarakat pesisir Indonesia. Contoh jenis rumput laut yang banyak dibudidayakan diantaranya adalah Euchemacottonii dan Gracelaria sp.

Mengkonsumsi rumput laut yang kaya akan kandungan serat, selenium dan seng dapat mereduksi estrogen. Disinyalir level estrogen yang terlalu tinggi dapat mendorong timbulnya kanker. Penelitian yang dilakukan terhadap penderita kanker di Amerika menunjukkan bahwa 
wanita yang melakukan diet ketat dengan mengkonsumsi serat tinggi dan mengurangi asupan lemak dari daging dan susu mempunyai level estrogen yang rendah. Hal ini didukung oleh hasil penelitian Harvard School of Public Health Amerika telah membuktikan bahwa pola konsumsi wanita Jepang yang selalu menambahkan rumput laut dalam menu makannya, menyebabkan wanita premenopause di Jepang mempunyai peluang tiga kali lebih kecil terkenakan kepayudara dibandingkan dengan wanita Amerika.

Luas wilayah Kecamatan Tinanggea secara keseluruhan dalah sebesar 354,74 Km2. Kecamatan Tinanggea memiliki potensi kelautan yang cukup besar, wilayah ini merupakan salah satu Kecamatan di Kabupaten Konawe Selatan yang memiliki sumberdaya alam laut yang baik, hasil laut seperti ikan dan rumput laut maupun tambak menjadi produksi utama diwilayah pesisir Kecamatan Tinanggea. Kegiatan pengabdian kepada masyarakat ini dilaksanakan di Desa Torekeku, sama halnya dengan desa pesisir lainnya Desa Torokeku juga memiliki potensi hasil laut seperti ikan-ikan pelagis dan ikan demersal, terkadang jika hasil perikanan melimpah ikanikan segar yang kaya akan nilai gizi ini terpaksa tidak dimanfaatkan karena cepat rusak dan tidak laku dijual walaupun dengan harga yang sangat murah. Hasil wawancara dengan kepala desa diperoleh informasi bahwa masyarakat belum mampu mengolah hasil perikanan secara baik melalui diversifikasi produk menjadi produk yang memiliki nilai tambah seperti mengolah ikan menjadi abon dengan kualitas yang baik, stik ikan dengan rasa yang lezat, nugget dan bakso ikan yang lebih enak dan sebagainya. Padahal potensi sumber daya manusia sangat tersedia untuk mengelola produk perikanan tersebut. Sehingga diperlukan alternatif pengolahan ikan menjadi produk yang lebih tahan lama dan diminati masyarakat melalui keterampilan pengolahan hasil perikanan dan kemampuan kewirausahaan yang juga sangat perlu dibina karena keterbatasan pengetahuan dan akses informasi serta edukasi/pendidikan (Fajriah, 2016).

Bakso atau baso adalah jenis bola daging yang lazim ditemukan pada masakan indonesia dan merupakan produk pangan yang terbuat dari daging atau ikan yang dihaluskan, dicampur dengan tepung, dibentuk bulat-bulat sebesar kelereng atau lebih besar dan dimasak dalam air panas hingga bakso tersebut mengapung. Bakso umumnya dibuat dari campuran daging sapi, ikan, ayam, udang, dan lain-lai. Dan tepung tapioka, dalam penyajian bakso umunya disajikan panas-panas dengan kuah kaldu, dicampur mi, bihun, taoge, tahu, terkadang telur dan taburi bawang goreng dan seledri, bakso sangat popular dan dapat ditemukan di seluruh Indonesia, berbagai jenis bakso sekarang banyak ditawarkan dalam bentuk makanan beku yang dijual di 
pasar sewalayan, bakso juga dapat dijadikan pelengkap jenis makanan lain seperti mie goreng,nasi goreng atau capcai.

Bakso daging menurut Standar Nasional Indonesia (SNI) No. 01-3818-1995 merupakan produk berbentuk bulatan atau bentuk lain yang diperoleh dari campuran daging (kadar daging tidak kurang dari $50 \%$ ) dan pati atau serealia dengan atau tanpa bahan tambahan makanan yang diizinkan (DSN, 1995). Bakso ikan hampir sama dengan bakso daging, perbedaanya hanya terletak pada bahan baku, yaitu ikan-ikan yang di gunakan dalam pembuatan bakso ikan bervariasi, tergantung rasa yang di inginkan kekenyalan dapat di atur berdasarkan tepung tapioca yang di gunkan.

Masyarakat lebih mengenal bakso sebagai makanan sepinggan yang dihidangkan dengan pelengkap lain seperti mie, sayuran, pangsit, dan kuah. Makanan ini sangat populer dan digemari oleh masyarakat. Hal ini terlihat dari banyaknya penjual mie bakso, mulai dari restoran sampai ke warung-warung kecil dan gerobak dorong. Harga satu porsi mie bakso sangat bervariasi tergantung dari kualitas baksonya.

Tujuan kegiatan pengabdian ini adalah untuk menggali permasalahan yang dialami oleh masyarakat nelayan Bajo di Desa Torokeku, Kecamatan Tinangge Kabupaten Konawe Selatan, di awal penyebaran COVID-19, dan di era new normal. Sasaran Kegiatan ini ditujukan bagi rumahtangga nelayan Bajo di Desa Torokeku, Kecamatan Tinangge Kabupaten Konawe Selatan.

\section{Permasalahan Mitra}

Kegiatan Pengabdian ini bertujuan untuk memberikan solusi dan bantuan dalam mengatasi permasalahan yang dialami oleh masyarakat nelayan Bajo di Desa Torokeku, Kecamatan Tinangge Kabupaten Konawe Selatan, di awal penyebaran COVID-19, dan di era new normal sebagai mitra kegiatan. Permasalahan yang dihadapi oleh masyarakat nelayan antara lain (1) Kemampuan untuk memproduksi olahan bakso ikan rumput laut masih terbatas karena ketersediaan modal khususnya untuk penambahan diversifikasi berbagai macam olahan pangan lainnya, seperti: kue-kue dari rumput laut, nugget rumput laut, sehingga produksi hanya dikonsumsi keluarga saja dan (2) belum adanya pangsa pasar yang memadai.

Solusi yang diberikan adalah: (1) Alih teknologi dengan memodifikasi proses pengolahan bakso ikan rumput laut sebagai inovasi makanan sehat dan rendah lemak dengan menggunakan peralatan yang sederhana; (2) Melakukan proses pengemasan dan pelabelan produk olahan 
bakso ikan rumput laut. Alih teknologi pengolahan bakso ikan rumput laut sebagai inovasi makanan sehat dan rendah lemak, dilaksanakan dengan cara memberikan pelatihan dan praktek secara langsung pada mitra kegiatan. Target yang diharapkan dapat tercapai setelah pelaksanaan kegiatan pengabdian diversifikasi olahan bakso ikan rumput laut adalah mitra dapat memproduksi makanan dengan memiliki kualitas dan kuantitas yang lebih baik, serta dapat memproduksi dengan olahan bakso ikan rumput laut sebagai produk yang memiliki cita rasa hygienis.

\section{B. METODE PELAKSANAAN}

Metode pelaksanaan kegiatan pengabdian kepada masyarakat ini dapat dilakukan dengan beberapa tahap, yaitu:

1) Penyuluhan dan Pelatihan

Penyadaran dengan memberikan penyuluhan berupa materi informasi dan pelatiahan guna meningkatkan keterampilan kepada mitra tentang manfaat Produk aneka olahan ikan, pemasaran online, serta nilai ekonomi yang dapat diperoleh melalui pembuatan aneka olahan ikan.

2) Pelatihan Manajemen

Pengelolaan usaha dan pemberian arahan tentang keberlanjutan produk aneka olahan ikan, pengemasan, sampai pemasaran secara online

3) Pendampingan Proses Produksi dan Pemasaran Online

Pendampingan terhadap mitra dalam membuat aneka olahan ikan hingga pemasaran secara online aneka olahan ikan

4) Monitoring dan Evaluasi program setelah pelaksanaan

\section{HASIL DAN PEMBAHASAN}

Konawe Selatan merupakan salah satu Kabupaten di Sulawesi Tengara yang meiliki potensi areal budidaya rumput laut.Luas ahan budidaya rumput laut Konawe Selatan mencapai 2.617 ha (DKP Sulawesi Tengara, 2019). Areal budidaya rumput laut Konawe Selatan terbesar di delapan kecamatan yaitu Kecamatan Tinanggea, Palangga Selatan, Laeya, Lainea, Moramo, Moramo Utara, Kolono, Dan Kecamatan Laonti.

Desa Torokeku merupaka desa terapung yang menjadi salah satu sentra produksi rumput laut yang ada di Kecamatan Tinanggea, dan sebagian besar penduduknya bermata pencaharian sebagai petani rumput laut yang berasal dari etnis Bajo, karena rumput laut juga 
merupakan salah satu produk unggulan sektor kelautan dan prikanan yang memiliki nilai jual tinggi. Letak Desa Torokeku yang berada diatas laut sangat strategis dalam mengembangkan budidaya rumput laut bagi para penduduknya, sehingga sangat potensial juga untuk pengembangan usaha olahan ikan rumput laut, karena dengan diversifikasi olahan tersebut dapat menambah pendapatan masyarakat nelayan Bajo. Kegiatan pengabdian Kepada Masyarakat dilaksanakan di Desa Torokeku yang merupakan salah satu desa dari 24 desa yang ada di Kecamatan Tinanggea. Jarak tempuh dari Kota Kendari ke Kecamatan Tinanggea sekitar 120 km dengan menggunakan transportasi darat. Sementara jarak tempuh dari Kecamatan Tinanggea ke Desa Torokeu sejauh 3 km dengan menggunakan juga menggunakan transportasi darat.

Kegiatan pengabdian ini melibatkan petani rumput laut dan keluarganya sehingga di dalam kelompok ada anggota pria, tetapi fokus introduksi pengolahan bakso ikan rumpu laut melibatkan anggota ibu-ibu dan remaja putri. Seperti halnya masyarakat lainnya di desa tersebut, banyak petani rumput laut ini juga menjual rumput laut dalam bentuk gelondongan. Meskipun sebagian besar petani rumput laut tersebut ini pernah mendapat pelatihan dari instansi terkait, tetapi belum menjadikan usaha ini sebagai usaha yang produktif. Diversifikasi produk olahan bakso ikan rumput laut untuk olahan makanan bisa difokuskan selain makanan pokok. Kebutuhan manusia terhadap bahan makanan tidak hanya terpenuhi dari bahan makanan pokok saja tetapi juga terdapat kebutuhan makanan tambahan. Snack merupakan salah satu jenis makanan tambahan digemari sebagian masyarakat dari berbagai kalangan. Snack yang terdapat di pasaran pada umumnya merupakan snack ekstrusi yang memiliki kandungan gizi rendah. Produk ekstrusi biasanya mengandung kadar protein yang rendah (Iqbal, Khalil, Ateeq, \& Kahn, 2006).

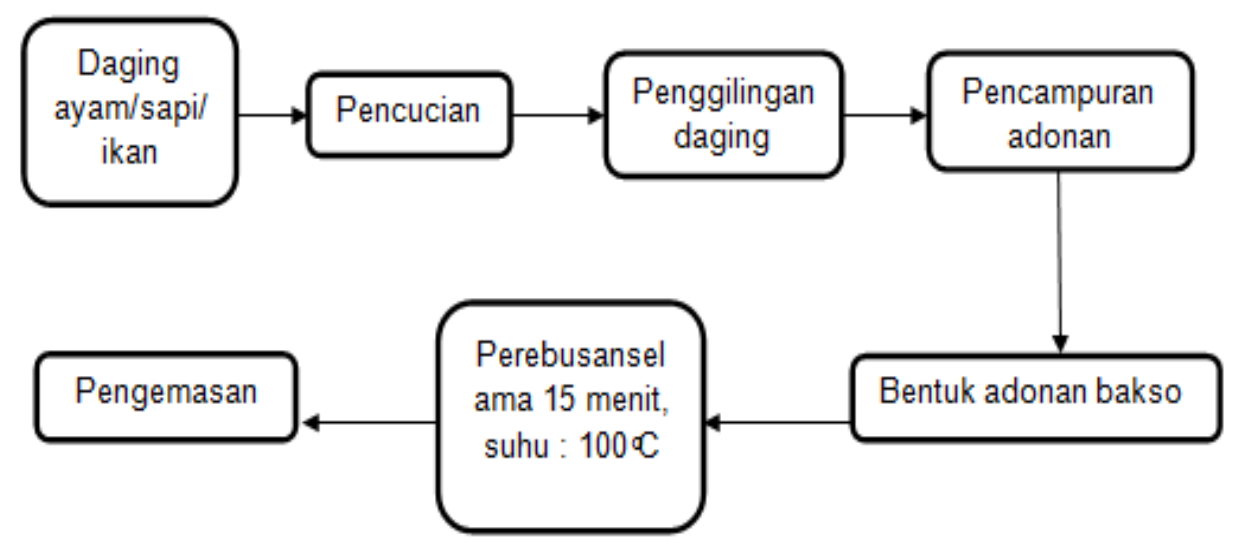

Gambar 1. Proses Pengolahan Bakso Ikan Rumput Laut 


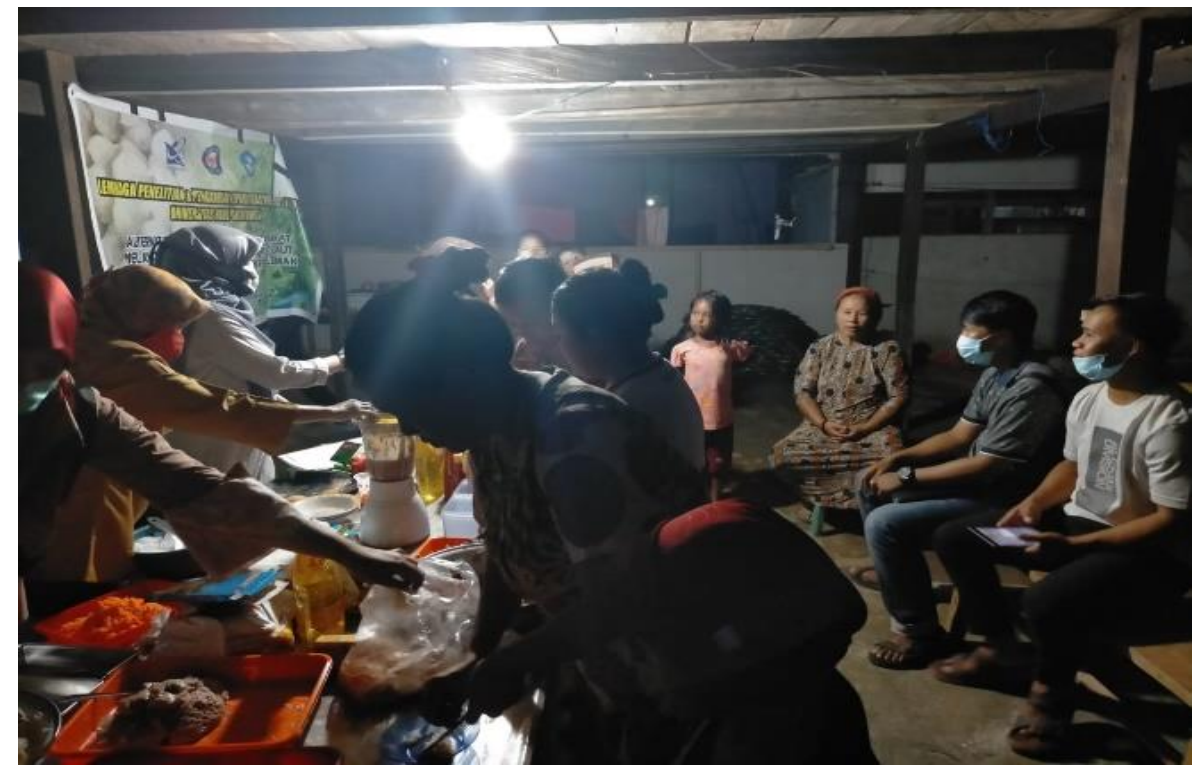

Gambar 2. Pemberian penyuluhan tentang manfaat rumput laut yang dapat diolah dengan cara olahan bakso ikan

Tahap kegiatan penyiapan bahan-bahan dan peralatan untuk produksi olahan bakso ikan rumput laut ini dilakukan dengan menyiapkan bahan-bahan untuk pembuatan olahan bakso ikan rumput laut. Rumput laut yang dipilih adalah dari jenis Eucheuma cottonii. Bahan rumput laut semua diadakan di lokasi pengabdian, sedangkan bahan yang lain juga diadakan di lokasi pengabdian kecuali bahan seperti tepung roti, tepung tapioka diadakan di Kota Kendari. Bahan pendukung lainnya semua diadakan di lokasi pengabdian. Pemilihan bahan baku yang digunakan disesuaikan dengan pangsa pasar. Pemilihan bahan baku rumput laut dilakukan dengan cara memilih rumput laut yang kadar garam dan kotoranya rendah. Rumput laut kering merupakan bahan baku dasar untuk semua produk olahan yang diintroduksikan (Gambar 3).
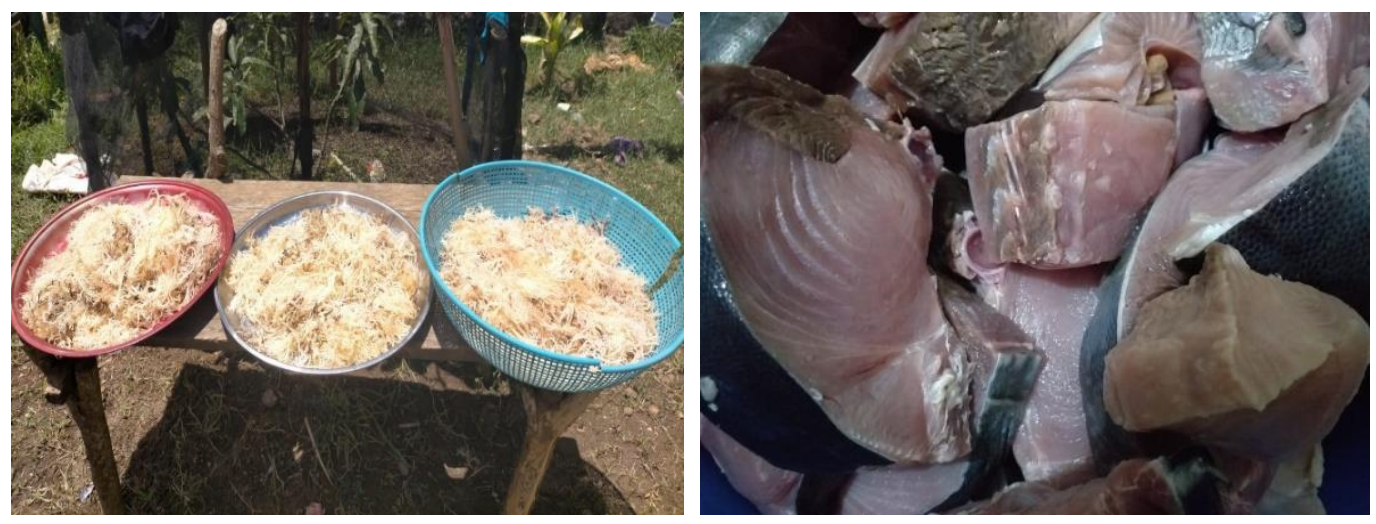

Gambar 3. Bahan baku rumput laut yang sudah direndam dan dijemur, ikan tongkol yang siap dibuat olahan bakso ikan rumput laut 


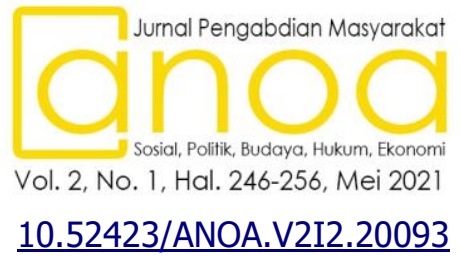

Tahap pelaksanaan produksi olahan bakso ikan rumput laut dilakukan dengan cara melibatkan seluruh ibu-ibu rumah tangga nelayan Bajo. Hasil yang diperoleh yaitu bakso ikan rumput lautr memiliki warna pada bakso putih pucat hal ini dipengaruhi dari rumput laut yang tak berwarna / tawar dan daging yang digunakan adalah daging ikan yang berwarna putih sehingga warnanya putih pucat. Teksturnya kenyal hal ini dipengaruhi dari rumput laut dan tepung tapioka serta STTP yang dapat mengenyalkan adonan bakso. Aroma dari bakso masih terasa amisnya mengingat bahan baku dari pembuatan bakso adalah rumput laut dan daging ikan dimana kedua bahan ini memiliki bau amis yang tinggi. Dan rasa dari bakso agak asin karena rumput laut yang telah mengandung garam / asin terlalu banyak jumlahnya dan pada saat penambahan garam juga terlalu banyak.

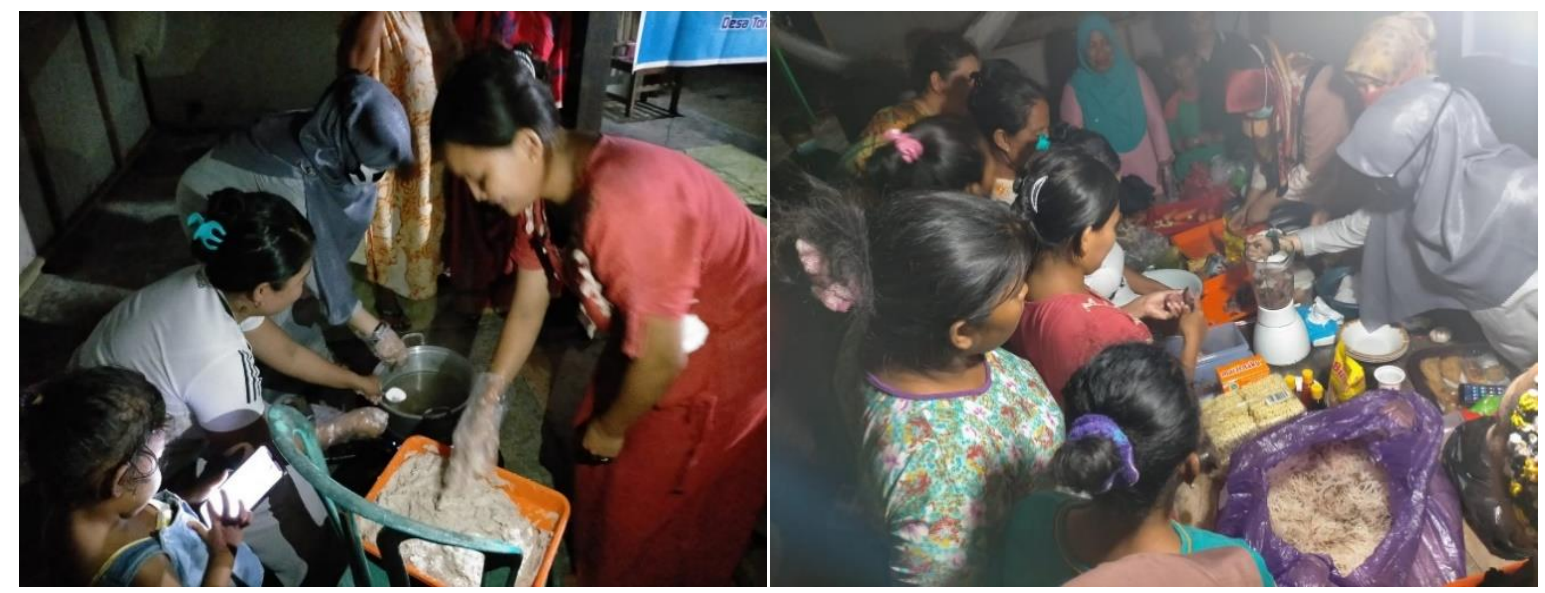

Gambar 4. Pelatiahan pembuatan olahan bakso ikan rumput laut

Hasil yang telah dicapai dari pelaksanaan kegiatan pengabdian kepada masyarakat adalah berjalannya seluruh kegiatan yang telah diprogramkan oleh tim pelaksana yang telah dirembukan secara bersama-sama oleh Kepala Desa Torokeku. Hasil nyata dari kegiatan pengabdian masyarakat secara umum adalah terjalinnya komunikasi yang baik antara seluruh masyarakat bajo yang terkenal cukup sulit berkomunikasi dengan masayarkat daratan di Desa Torokeku, dengan pihak akademisi yang berasal dari Universitas Halu Oleo Kendari. Adapun Programprogram dari kegiatan pengabdian kepada masyarakat yang ada di Desa Torokeku yang telah dihasilkan adalah sebagai mana pada Tabel 1. 
Tabel 1. Program dan Kegiatan Pengabdian Kepada Masyarakat di Desa Torokeku Kecamatan Tinanggea

\begin{tabular}{|c|c|c|c|}
\hline No. & Program & Kegiatan & Hasil yang telah dicapai \\
\hline 1. & $\begin{array}{l}\text { Peningkatan } \\
\text { kapasitas } \\
\text { kewirausahaan }\end{array}$ & $\begin{array}{l}\text { Pelatihan kewirausahaan } \\
\text { tentang perencanaan usaha, } \\
\text { manajemen keuangan, } \\
\text { manajemen produksi, sistem } \\
\text { pemasaran dan distribusi } \\
\text { barang, dan kiat-kiat menjadi } \\
\text { pengusaha sukses. }\end{array}$ & $\begin{array}{l}\text { - Timbulnya minat dan } \\
\text { keinginan masyarakat nelayan } \\
\text { untuk berusaha atau } \\
\text { menciptakan lapangan kerja } \\
\text { baru dibidang peikanan } \\
\text { khususnya olahan rumput laut } \\
\text { - Bertambahnya pemahaman } \\
\text { pengusaha yang sudah ada }\end{array}$ \\
\hline \multirow[t]{3}{*}{2.} & \multirow[t]{3}{*}{$\begin{array}{l}\text { Peningkatan } \\
\text { nilai ekonomi } \\
\text { produk olahan } \\
\text { rumput laut }\end{array}$} & $\begin{array}{l}\text { a. Pelatihan olahan rumput } \\
\text { laut menjadi bakso ikan } \\
\text { rumput laut }\end{array}$ & $\begin{array}{l}\text { - Bertambahnya pengetahuan } \\
\text { dan keterampilan ibu-ibu } \\
\text { rumah tangga nelayan dalam } \\
\text { mengolah rumput laut } \\
\text { menjadi olahan bakso ikan } \\
\text { rumput laut }\end{array}$ \\
\hline & & $\begin{array}{l}\text { b. Pelatihan tentang } \\
\text { diversifikasi produk } \\
\text { perikanan khususnya } \\
\text { rumput laut }\end{array}$ & $\begin{array}{l}\text { - Menghasilkan produk olahan } \\
\text { perikanan yang layak dijual } \\
\text { dalam bentuk siap saji } \\
\text { maupun siap untuk dimasak }\end{array}$ \\
\hline & & $\begin{array}{l}\text { C. Sosialisasi keamanan } \\
\text { produk hasil olahan } \\
\text { rumput laut }\end{array}$ & $\begin{array}{l}\text { - Peningkatan pengetahuan dan } \\
\text { pemahaman dalam menglah } \\
\text { makanan dan bahan alam } \\
\text { yang aman namun tetap } \\
\text { berkualitas, higienis, dan tetap } \\
\text { memiliki daya saing tinggi. }\end{array}$ \\
\hline
\end{tabular}
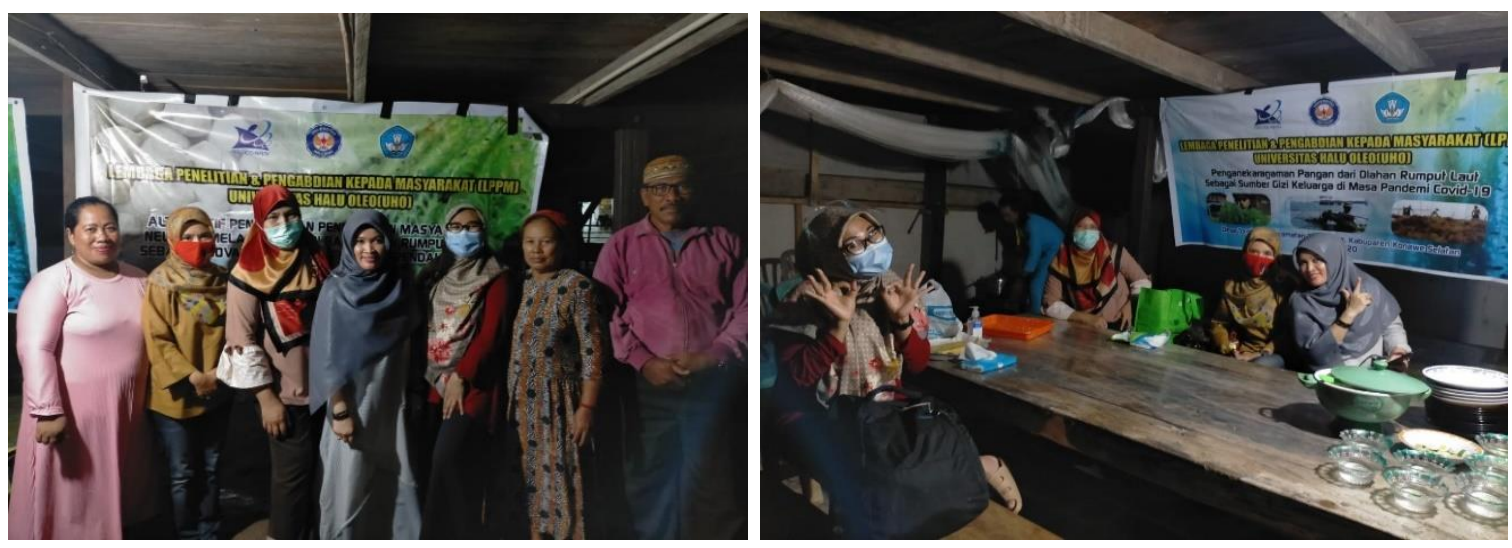

Gambar 5. Foto bersama Tim Pelakasana kegiatan pengabdian dengan peserta kegiatan 


\section{PENUTUP}

\section{Kesimpulan}

Pada pembuatan bakso ikan rumput laut dilakukan dengan membersihkan bahan yang akan digunakan mulai dari rumput laut dan ikan yang akan digunakan. Selanjutnya masuk ketahap pembuatan adonan dan penambahan bahan lainnya serta perebusan hingga matang. Hasi dari kegiatan pengabdian kepada masyarakat ini yang sasaranya adalah masyarakat nelayan bajo, dapat dilihat dari peningkatan pengetahuan dan keterampilan dalam melakukan usaha olahan ikan rumput laut, juga terdapat peningkatan pendapatan dan nilai tambah rumput laut, sehingga dengan adanya diversifikasi olahan tersebut dapat membantu nelayan bajo khususnya pada saat musim paceklik.

\section{Saran}

Saran dari pembuatan bakso ikan rumput laut sebaiknya tepung tapioka yang digunakan disesuaikan, usahakan takaran pas dengan prosedur agar hasilnya baik dan tidak lunak. Kekompakan antara anggota perlu semakin ditingkatkan

\section{DAFTAR PUSTAKA}

Azis, Andi Risqa. 2017. ModulJobshetTeknologi Proses Agro I. Makassar :Politeknik ATI Makassar"Kamis, 20 April 2017, 19.02 WITA

http://baso-sugih.blogspot.co.id/2016/05/definisi-bakso.html"Kamis, 20 April 2017, 20.10 WITA.

http://lakombulo.blogspot.co.id/2015/06/makalah-pembuatan-bakso-ikan.html "Kamis, 20 April 2017, 20.20 WITA.

Badan Pusat Statistik (BPS) Sulawesi Tengara, 2019, Kecamatan Tenanggea Dalam Angka 2019, Badan Pusat Setatistik Provensi Sulawesi Tengara, Kendari.

Badan Standarisasi Nasional. 1995. Bakso Daging. SNI 01-3818-1995. BadanStandarisasi Nasional. Jakarta "Kamis, 20 April 2017, 20.24 WITA.

BPD Desa Torokeku (2018). Laporan Kegiatan Desa Torokeku, Kecamatan Tinanggea, Kabupaten Konawe Selatan.

Fajriah, Tamtama, A., \& Isamu, K. T. (2016). Pemanfaatan hasil tangkapan sampingan untuk meningkatkan nilai jual hasil perikanan sero di pulau bungkutoko. Dalam Prosiding Seminar Nasional dan Gelar Produk (Senaspro 2016). Universitas Muhammadiyah Malang, Malang, 17-18 October 2016 (pp. 94-98). Malang: UMM Press.

Ilalqisny I, Widyartini. 2000. Makroalga. Purwokerto (ID): Universitas Jendral Soedirman. 153 HIm.

Iqbal,A., Khalil, I., Ateeq, N., \& Kahn, M. (2006). Nutritional quality of important food legumes., Food Chemi(97), 331-335. 
Kadi A. 2004. Potensi Rumput Laut Dibeberapa Perairan Pantai Indonesia. Oseana. XXIX (4): 2536.

Suparmi, Sahri A. 2009. Mengenal Potensi Rumput Laut: Kajian Pemanfaatan Sumber Daya Rumput Laut Dari Aspek Industri Dan Kesehatan. Majalah IImiah Sultan Agung. 44(118): 95-116. 